\title{
IMPACT OF COVID-19 PANDEMIC ON SCHOOL EDUCATION IN INDIA: CHALLENGES AND OPPORTUNITIES
}

\author{
Kartik Barad ${ }^{1}$, Santosh Kumar Parida ${ }^{2}$, Kunu Nayak ${ }^{3}$ \\ ${ }^{1}$ Research Scholar, Zakir Hussain Centre for Educational Studies, Jawaharlal Nehru University, \\ New Delhi, India \\ ${ }^{2}$ Integrated B.Ed.-M.Ed. Student, Regional Institute of Education (NCERT), Bhopal, India \\ ${ }^{3}$ Research Scholar, Central Institute of Education, University of Delhi, New Delhi, India
}

Article DOI: https://doi.org/10.36713/epra9403

DOI No: $10.36713 /$ epra9403

\begin{abstract}
The pandemic COVID-19 has significantly hampered every aspect of human life, including education worldwide. Every school is closed to control the spread of the global pandemic COVID-19. Sudden closure of schools brings difficulties to carry on with face-to-face classroom teaching. So, online education is a panacea to continue the education system in India. However, the lack of technological awareness among teachers and students, network infrastructures, computers, and internet access create a challenging situation in handling the school education system. This paper analyses the impact of the COVID-19 pandemic on the school education system in India. Based on the published articles, documents, reports, and news commentaries, this paper provides a critical analysis and reflection on the challenges and opportunities created by the global pandemic COVID-19 in the school education system of India. The study revealed that schools, teachers, and students do not have sufficient infrastructure like configured laptops, internet, microphones, etc., to efficiently impart education and significant problems raised in the field of E-learning atmosphere, Pedagogical practices, Curricular and Co-curricular activities, and Evaluation and feedback.
\end{abstract}

KEY WORDS: COVID-19, School Education, Challenges, Opportunities

\subsection{INTRODUCTION}

In the 21 st century, every child has to be educated by starting their schooling career. But today, COVID-19 has affected many students across the country irrespective of caste, class, gender, and region. The closing down of schools and the decision to shift conventional to a digital platform are increasing learning inequality among students and pushing many students out of school due to the digital divide. As of July 2020, $98.6 \%$ of learners worldwide were affected by the pandemic, representing 1.725 billion children and youth, from pre-primary to higher education, in 200 countries (United Nations, 2020). All the educational activities like examinations, school admission, learning methodology, teaching techniques, \& assessment methodologies are quite affected due to the global pandemic COVID-19. Due to the unavailable internet connectivity, information technology, educational materials, and digital technology skills, e-learning is difficult for teachers and students in developing countries (Mustafa, 2020).

India is the second-most affected COVID-19 country after the United States of America in the world (Worldometer,2021). So, it is the challenge of the Indian government to prevent the spread of the COVID-19 pandemic. The Indian government had taken various measures to prevent the spread of the COVID-19 pandemic, such as lockdown and shutdown, resulting from the closure of all educational institutions in India. Classes were suspended, and all examinations of schools were postponed indefinitely. Thus, the lockdown adversely affects the education of most of the students. Though it is an exceptional circumstance in the history of school education, the COVID-19 pandemic has created many opportunities to come out of the rigorous classroom teaching model to a new era of digital technology. The lockdown has given both teachers and students a chance to continue their educational activities online. The teachers assigned 
work to students via the internet and delivered lectures through live video conferencing using different Apps like Zoom, Google Meets, Facebook, YouTube, etc. There are many digital initiatives developed by the government of India, such as DIKSHA, e-PATHSALA, SWAYAM, SWAYAM PRAVABHA, National Digital Library, etc., which is created an opportunity for both school teachers and students to continue their teaching and learning. Though, it produces many options that similarly increase the challenges for students who belong to deprived sections to attend online classes using any technological devices.

\subsection{SIGNIFICANCE OF THE STUDY}

The closing down of schools and the decision to shift conventional to a digital platform are increasing learning inequality among students and pushing many students out of school due to the digital divide. By considering this, the study is conducted to analyse the impact of COVID-19 on India's School Education system.

The pandemic adversely affects the education system and creates opportunities for the school, teachers, and students. There are several questions coming to the field of education is need to be clarified, such as 1) Whether the school is ready to deal with the adverse effects of COVID-19, 2) how the school infrastructural is structured and digitally versed, 3) How the teachers and students are prepared, 4) What are alternative modes and opportunities for the stakeholders. Hence, the researcher is keenly interested in highlighting the key challenges and opportunities in the field of education due to the impact of COOVID-19. The findings of the study will help the school, teacher, students, policymaker, and curriculum designer in dealing with the impact of COVID-19 on education. The study will also create a level of awareness among the stakeholders on various challenges and opportunities about school education due to the impact of COVID19.

\subsection{OBJECTIVE OF THE STUDY}

1. To review the challenges in teaching and learning in the school education due to the impact of the COVID-19 pandemic in India with reference to:

- School, teacher and students' preparedness

- E-learning atmosphere

- Pedagogical practices

- Curricular and Co-curricular activities

2. To analyse the opportunities in teaching and learning in school education system by the impact of COVID-19 in India

\subsection{RESEARCH QUESTIONS}

1) What are the challenges in teaching and learning in the school education system due to the impact of the COVID-19 pandemic in India?

2) What are the opportunities in teaching and learning in school education system by the impact of COVID-19 in India?

3) What are the suggestive measures for the challenges and the profit utilisation of opportunities due to the impact of the COVID-19 pandemic?

\subsection{RESEARCH METHODOLOGY}

Data and information that emerged in this paper are collected from the various reports and articles published by national and international agencies on the impact of the COVID-19 pandemic on the school education system. Some information is also collected from various authentic websites, Newspapers. Some reputed journals relating to the impact of COVID-19 on the school education system are referred.

\subsection{RESULTS AND DISCUSSION}

After reviewing related studies and various papers concerning the impact of COVID-19 on school education, the investigator revealed several common challenges and opportunities in school education. The result can be categorized into two significant heads as challenges and opportunities, pointing to the impact of COVID-19 on school education.

\subsection{Challenges in teaching and learning in the school education}

Both teachers and students face many obstacles related to teaching and learning during the COVID-19 pandemic. A lack of introductory provisions, external distractions, and family interruption during teaching and learning were major issues noticed at home. In school education, various parts are affected. Here, the researcher highlighted some major dimensions concerning School, teacher and students' preparedness, E-learning atmosphere, Pedagogical practices, Curricular and Co-curricular activities, and Evaluation and feedback.

School, teacher and students' preparedness: Joshi et al. (2020) has identified several barriers that affect online teaching of student's in-home environment settings like technical difficulties, lack of coaching, lack of institutional support, lack of technical support, difficulty in course integration with technology, unavailability of essential opportunities, outside distraction, personal problems faced by teachers in online teaching and assessments. During the online teaching-learning process, teachers have faced several challenges, like network issues, lack of training, lack of awareness, lack of interest, lack of 
personal touch, and lack of interaction (Arora and Srinivasan, 2020). Sudevan and Almaiah et al. (2020) has revealed that teachers were teaching online with no proper training. Because of a scarcity of training, teachers face many problems in using technology for teaching.

Teachers aren't having sufficient infrastructure like configured laptops, internet, microphones, etc., to impart education efficiently. Most of the teachers face connectivity issues, system failure, and bandwidth issues while conducting online sessions, and because of a lack of technical assistance, they're unable to resolve problems. Teachers also found it challenging to manage the scholars once they teach online. Most frequently, students deliberately create indiscipline by playing music, making noise, posting nasty comments through fake users, eating, playing games in several windows (Punit \& Qz.com, 2020).

E-learning atmosphere: At present, technology is so fast in various countries. E-learning doesn't appear suddenly due to Covid but has been implemented in several countries. However, its implementation is supported by face-to-face learning. So, when the pandemic occurs, several countries are ready to enforce policies on online education like technology tools, the internet, readiness of educational elements (students, teachers/lecturers, parents). This is often in contrast to India's willingness to implement online learning policies. The govt, school, and other stakeholders aren't adequately ready to introduce online learning.

Hence, creating an E-learning atmosphere without required accessories and training was a severe challenge to the state and teachers. Teachers and students don't have sufficient infrastructure like configured laptops, internet, microphones, etc. to cater to education efficiently. The home atmosphere isn't suitable for both teachers and students. Several barriers that affect online teaching of students and teacher's in-home environment settings like technical difficulties, lack of training, lack of institutional support, lack of technical facilities, lack of clarity \& direction, difficulty in course integration with technology, external distraction, and family interruption and personal problems faced by teachers in online teaching and assessments. Especially in a country, most students have limited or no internet access. Many students might not be ready to afford a computer, laptop, or supporting mobile phones in their homes; online teaching-learning may create a digital divide among students. Primarily, school students need to deal with various sorts of ecological, electronic, and mental battles because of the COVID19 pandemic (Garg, Aggarwal, et al.2020).

Pedagogical practices: The sudden shift to online learning with no planning, particularly during a developing country like India where the backbone of online education wasn't prepared, and therefore the curriculum wasn't constructed for such a format, has created the danger of most of our youngsters becoming passive learners. The Corona Virus has made institutions travel from offline to online pedagogy. This crisis will make the institutions, which were earlier reluctant to vary, accept modern technology. This catastrophe will show us the lucrative side of online teaching and learning. With the assistance of online teaching modes, we will sermonize an excessive number of scholars at any time and in any part of the planet. All institutions must scramble different online pedagogical approaches and check out to use technology more aptly. Many universities worldwide have fully digitalized their operations, understanding the dire need of this current situation. There was an overnight shift of regular classrooms into e-classrooms; educators have shifted their pedagogical approach to tackle new market conditions and adapt to the changing situations. During this challenging time, the priority isn't about whether online teaching-learning methods can provide quality-education.

Curricular and Co-curricular activities: All the faculties are closed, and classes are suspended. The different boards have already postponed India's annual examinations and entrance tests. The varsity curriculum wasn't ready consistent with the moment requirement of the circumstances. It had been a massive challenge for the varsity to accommodate the curriculum with the stipulated time and available resources. Because of the shutdown of faculties, cocurricular activities like sports, drills, and physical work hinder measurably.

\subsection{Opportunities for teaching and learning}

Though the sudden impact of COVID-19 has created many challenges on school education, the educational institution of India has accepted the challenges and trying its best to provide seamless support services to the students and teachers during the pandemic. Indian education system got the opportunities for transformation from a traditional approach to a new technological era. The following points may be considered as opportunities created by the COVID-19 pandemic.

World classrooms: Due to COVID-19, all schools were closed in India, and it brought an opportunity for people to connect from all over the world. The students of India were able to interact with the worldclass teacher. The teacher could share their knowledge with a larger student population via conferences, Zoom, and the google meets app. However, both students and teachers can now explore and widen their knowledge (Jena, 2020). 
Upgrade in collaborative work: Now, information technology has constructed it easy to learn and teach in the group. There is a new chance for collaborative teaching and learning to take on new forms. Collaboration can also happen among teachers and students across the country to benefit from each other (Mishra, 2020).

Access to various learning resources: In the era of COVID-19, the learning resources are being widened and widened. The students access a variety of relevant learning resources by using the internet. Millions of information can be collected using the internet or other digital resources. It helps the students for self-learning by sitting their own home.

The rise in online meetings and seminars: A large number of academic discussions, seminars, conferences, the workshop will move to online mode, and there is a possibility that some new form of the online conferencing platform will emerge as a business model. Google meet, zoom cloud meeting, Microsoft team, Facebook and YouTube, etc., are the weapons for the continuing seminar and meeting online.

Any time anywhere learning: Many students and teachers could not attend face-to-face class due to the outbreak of the COVID-19 pandemic. Now they can attend all the classes and learn anytime and anywhere. It is possible through the transformation of traditional learning to modern technological knowledge.

Improvement of digital literacy: The pandemic circumstance-initiated students to learn and utilize advanced innovation and expanded digital literacy among students. Most of the students of India will use a mobile phone, laptop, or any other technological device that results in the improvement of digital literacy among students.

Creation of a blended classroom: The COVID-19 has created a new opportunity for the blended classroom. A blended classroom is an environment where learning is done using both the offline and online methods and techniques of teaching. It is the panacea for learning during the COVID-19 pandemic situation.

Improvement in learning materials: There is an excellent opportunity for schools to improve the learning material used in the teaching-learning process. In the lockdown period, students cannot collect hard copies of study materials, and hence most of the students used soft copy materials for reference.

\subsection{SUGGESTIONS}

1) In this pandemic situation, the Govt. and educational institutions should apply innovative methods to include all the students (irrespective of their caste, gender, religion, region and disability etc.) in the mainstream of education.

2) Policy should be adopted by Government/educational institutions to provide free internet and free digital gadgets to all learners in order to encourage online learning as a result of which people would get engaged and remain safe during pandemic (Pravat,2020c).

3) Educators and learners should be trained to utilize online teaching learning process using technology during COVID-19 period.

4) If pandemic COVID-19 continues, academic assessment of the students should be done through online mode or through quizzes and small projects.

5) At present, access to technology and the internet is an urgent need. So, the digital technologies and the required infrastructure must reach the remotest villages to facilitate the students' education during the COVID-19 period.

6) The govt. of India and educational institutions should take special steps/measures/initiatives for deprived section students to continue their education.

7) Proper education of student is the heart of Indian education system. So, the schools should be reopening as per the COVID-19 guidelines.

\subsection{Conclusion}

COVID-19 has impacted extremely to the school education system across the nation. Though it has created many difficulties, various opportunities are also expanded. The Indian Govt. and educational institutions have explored the possibility of virtual learning by adopting different digital technologies to cope with the current crisis of COVID-19. Each educational institution needs to improve its knowledge and information technology infrastructure to be ready for facing global pandemic COVID-19 like situations. India should develop innovative methods to ensure that all children have sustainable access to learning during a lockdown situation. For further detail, a statistical study may be undertaken to explore the impact of COVID-19 on the school education system in India.

\section{REFERENCES}

1. Arora, A. K., \& Srinivasan, R. (2020). Impact of Pandemic COVID-19 on the Teaching-Learning Process: A Study of Higher Education Teachers. Prabandhan: Indian Journal of Management, 13(4), 43-56. Retrieved from 
http://indianjournalofmanagement.com/index.php /pijom/article/view/151825.

2. Garg, S., Aggarwal, D., Upadhyay, S. K., Kumar, G., \& Singh, G. (2020). Effect of COVID-19 on school education system: Challenges and opportunities to adopt online teaching and learning. Humanities and Social Science Review, 8(6), 10-17.

3. Jain, S., Lall, M., \& Singh, A. (2021). Teacher's Voice on The Impact of COVID-19 on School Education: Are Ed-Tech Companies Really the Panacea? Contemporary Education Dialogue, 18(1),58-59.

4. Jena, K. P. (2020).Impact of PandemicCOVID19 on Education in India. International Journal of current Research,12(7),12582-12586. doi:https://doi.org/10.24941/ijcr.39209.07.2020.

5. Jena, K. P.(2020a). Challenges and Opportunities created by Covid-19 for ODL: A case study of IGNOU. International Journal for Innovative Research in Multidisciplinary Filed, Volume-6, Issue- 5, Pg. 217-222

6. Joshi, A., Vinay, M. \& Bhaskar., (2020). Impact of Coronavirus Pandemic on the Indian Education Sector: Perspectives of Teachers on online teaching and assessments. Interactive Technology and Smart Education. Retrieved from https://www.researchgate.net/publication/343961 926.

7. Koul, P. P. (2020). Impact of COVID-19 on Education Sector in India. Journal of Critical Review,7(11),3919-3930

8. Mishra, K. (2020, May12). COVID-19:4Negative Impacts and 4 Opportunities Created for Education. India Today. Retrieved from https://www.indiatoday.in/educationtoday/featurephilia/story/covid-19-4-negativeimpacts-and-4-opportunities-created-foreducation-1677206-2020-05-12.

9. Mustafa, N. (2020). Impact of the 2019-20 Coronavirus Pandemic on Education. International Journal of Health Preferences Research, 1-12.

10. Pokhre, S., \&Chhetri, R. (2021). A Literature Review on Impact of COVID-19 Pandemic on Teaching and Learning. Higher Education for Future, 8(1), 133-142

11. Punit, I. S., \& Qz.com. (2020, May 13). For many of India's teachers, online classes amid lockdown have been an awful experience [Web log post]. Retrieved from https://scroll.in/article/961738/for-many-ofindias-teachers-online-classes-amid-lockdownhave-been-an-awful-experience

12. Rawal, M. (2021). An Analysis of COVID-19 impacts on Indian Education System. Educational Resurgence Journal,2(5),35-40

13. Sudevan, P. (2020). Why E-learning isn't a sustainable solution to the COVID-19 education crisis in India [Web log post]. Retrieved from https://www.thehindu.com/scitech/technology/why-elearning-is-not-asustainable-solution-to-the-covid19-educationcrisis-in-india/article31560007.ece
14. Tarkar, P. (2020).Impact of Pandemic on Education System. International Journal Of Advance Science and Technology,29(9),38123814

15. Tadesse, S., \& Muluye, W. (2020). The Impact of COVID-19 Pandemic on Education System in Developing Countries: A Review. Open Journal of Social Sciences, 8, 159-170.

16. United Nation. (2020). Policy Brief: Education During COVID-19 and beyond. United Nations.https://www.un.org/development/desa/ds pd/wpcontent/uploads/sites/22/2020/08/sg_policy _brief_covid-19_education-august-2020.pdf. 